\title{
Productivity Enhancement of Rabi Groundnut (Arachis hypogaea L.) under Polythene Mulching and Rhizobium Inoculation under New Alluvial Zone of West Bengal, India
}

\author{
Mousumi Mondal*, Sunil Kr. Gunri, Amrita Sengupta and Rajib Kundu \\ Department of Agronomy, Bidhan Chandra Krishi Viswavidyalaya, Mohanpur, \\ West Bengal, India \\ *Corresponding author
}

\section{Keywords}

Groundnut, Polythene mulch, Rhizobium, Biofertilizers and yield

Article Info

Accepted:

16 August 2018 Available Online: 10 September 2018

\section{A B S T R A C T}

The experiment was conducted during rabi season of 2015-16 and 2016-17 at District Seed Farm under Bidhan Chandra Krishi Viswavidyalaya, Mohanpur, Nadia, West Bengal with a view to performance of rabi groundnut under polythene mulch and finally to validate the productivity enhancement through inoculation of newly isolated rhizobium. The design of the experiment was split plot with three replications. The main plot comprises viz., Mo: Without mulch; M1: With mulch and subplot treatment was nutrient management viz., F1: 100\% RDN; F2: $75 \%$ RDN; F3: $50 \%$ RDN; F4: 100\% RDN+ rhizobium; F5: 75\% RDN+ rhizobium; F6: 50\% RDN+ rhizobium; F7: Rhizobium. White, transparent 7 micron polythene was used as mulching. The newly isolated rhizobium strain was inoculated with groundnut variety TG51. Germination \% was found maximum and days to germination were less under polythene mulch as compared to without mulch. Plant height increased steadily under both polythene mulching and soil application of inorganic fertilizer $(100 \%$ of RDN) along with rhizobium. Dry matter production, CGR and number of nodules plant $^{-1}$ were further influenced under inorganic fertilizer application to groundnut rather polythene mulch but it was further increased when rhizobium was supplemented with inorganic fertilizer. Polythene mulch had greater influence to increase the yield attributes and kernel yield of groundnut and significantly higher kernel yield was found under polythene mulch over without mulch. Incremental doses of soil application of inorganic nitrogen either $75 \%$ or $100 \%$ of RDN gave the higher kernel yield as compared to $50 \%$ of RDN. Higher BCR was found under polythene mulch treatment and $100 \%$ RDN along with rhizobium. $25 \%$ of soil application of inorganic nitrogen could be replaced by inclusion of location specific strain of a fresher rhizobium to achieve the optimum yield of groundnut kernel.

\section{Introduction}

Groundnut is considered as a cash crop by the farmers and fluctuation in its yield affects the farmers' economy. It is the world's fourth most important source of edible oil and third most important source of vegetable protein (Kamble et al., 2018). In India the rabi/summer crop gives significantly higher yields than kharif crop: this is because of favourable climatic 
conditions for growth and development of crop and low incidence of pests and diseases. Though, India is one of the largest groundnut growing countries in the world but the productivity is very low. This is mainly because, 90 per cent of groundnut growing area is under rainy season which results in low seed multiplication ratio (1:3). Although, the productivity and seed multiplication ratio (1:8) of rabi/summer raised groundnut crop is more. Biofertilizers are the source of microbial inoculants, which have brought hopes for many countries both economically and environmentally.

Therefore, in developing countries like India, biofertilizers can solve problems of high cost of fertilizers and thus can save the economy of the country. The lower soil temperature especially during germination, peg initiation and pod filling stages is another major problem in rabi/summer groundnut cultivation. The present experiment was undertaken to judge the efficacy of newly isolated rhizobium for fertility build up in rabi season groundnut under polythene mulch for boosting up of germination ability under low soil temperature and finally to validate the yield enhancement.

\section{Materials and Methods}

The field experiment was under taken during rabi season of 2015-16 and 2016-17 under Bidhan Chandra Krishi Viswavidyalaya, Nadia, West Bengal. The experiment was laid out in split plot design with three replications where the main plot treatment was polythene mulching viz., Mo: Without mulch; M1: With mulch and subplot treatment was nutrient management viz., F1: 100\% RDN; F2: $75 \%$ RDN; F3: 50 \% RDN; F4: 100\% RDN+ rhizobium; F5: 75\% RDN+ rhizobium; F6: 50\% RDN+ rhizobium; F7: Rhizobium. The groundnut variety TG51 was sown during both the years. Transparent, white with 7 micron thickness polythene sheet of one meter width was spread immediately after sowing with a spacing of $30 \mathrm{~cm} \times 10 \mathrm{~cm}$ under both with mulch and without mulch treated plot. The newly isolated rhizobium strain was inoculated which has ability to reduce $25 \%$ soil application of inorganic nitrogen to groundnut during summer season. All good agronomic management was followed during both the years of experimentation.

\section{Results and Discussion}

\section{Effect on plant growth}

Polythene mulch had remarkable influence on germination $\%$ of rabi groundnut as the polythene mulch restore more moisture in the soil including increasing the soil temperature, supply of uniform soil moisture and reduce the soil compaction around the pod zone which helps to promote the radical and plumule faster as a result of quicker germination with minimum days to germination as compared to without mulch. Similar observation was also reported by Deshwal et al., (2003). Nitrogenous fertilizer along with or without rhizobium had also significant effect on germination \%. Plant height or shoot height is an integral part of the crop growth which is the main architecture of crop canopy leads to crop developmental processes. Plant height of groundnut increased with increase the age of the crop and found maximum towards maturity irrespective of the treatments. Plant height at all the stages increased due to polythene mulching but it was not comparable with the plant height recorded under without mulch. Plant height increased with increasing doses of inorganic nitrogen but plant height increased further when rhizobium was supplemented with inorganic nitrogen irrespective of their doses $50 \%, 75 \%$ or $100 \%$ of RDN, rhizobium with groundnut kernel had the significant influence to increase the plant height over without inoculation (Table 1). 
Table.1 Growth of rabi groundnut as influenced by polythene mulching and rhizobium inoculation (Pooled over two year)

\begin{tabular}{|c|c|c|c|c|c|c|c|c|c|c|}
\hline \multirow{2}{*}{\multicolumn{3}{|c|}{ Treatment }} & \multirow[t]{2}{*}{$\begin{array}{l}\text { Germinatio } \\
\text { n }(\%)\end{array}$} & \multirow{2}{*}{$\begin{array}{l}\text { Days to } \\
\text { germinati } \\
\text { on }\end{array}$} & \multicolumn{2}{|c|}{ Plant height (cm) } & \multicolumn{3}{|c|}{$\begin{array}{l}\text { Dry Matter Production } \\
\left(\mathrm{g} \mathrm{m}^{-2}\right)\end{array}$} & \multirow{2}{*}{$\begin{array}{l}\text { Number of } \\
\text { nodules } \\
\text { plant }^{-1}\end{array}$} \\
\hline & & & & & $\begin{array}{l}45 \\
\text { DAE }\end{array}$ & $\begin{array}{l}\text { At } \\
\text { Harvest }\end{array}$ & $\begin{array}{l}45 \\
\text { DAE }\end{array}$ & $\begin{array}{l}60 \\
\text { DAE }\end{array}$ & $\begin{array}{l}75 \\
\text { DAE }\end{array}$ & \\
\hline \multicolumn{11}{|c|}{ Mulching (M) } \\
\hline $\mathbf{M}_{0}$ & & Without mulching & 87.4 & 11.5 & 24.8 & 40.7 & 117.5 & 203.7 & 265.9 & 48.5 \\
\hline $\mathbf{M}_{1}$ & : & With mulching & 94.7 & 5.4 & 35.2 & 45.9 & 124.7 & 216.0 & 290.9 & 53.8 \\
\hline \multicolumn{3}{|c|}{$\operatorname{SEm}( \pm)$} & 0.26 & - & 0.15 & 0.15 & 1.05 & 2.48 & 0.63 & 2.21 \\
\hline \multicolumn{3}{|c|}{$\mathrm{CD}(\mathrm{P}=0.05)$} & 0.71 & - & 0.41 & 0.41 & 2.88 & 6.80 & 1.72 & NS \\
\hline \multicolumn{11}{|c|}{ Nutrient management (F) } \\
\hline $\mathbf{F}_{1}$ & $\cdot$ & $100 \% \mathrm{RDN}$ & 93.0 & 8.5 & 31.1 & 45.0 & 129.3 & 225.6 & 292.6 & 56.2 \\
\hline $\mathbf{F}_{2}$ & : & $75 \% \mathrm{RDN}$ & 92.3 & 8.5 & 30.4 & 43.8 & 126.9 & 221.2 & 290.1 & 53.2 \\
\hline $\mathbf{F}_{3}$ & : & $50 \% \mathrm{RDN}$ & 92.3 & 8.5 & 29.3 & 42.4 & 121.2 & 213.7 & 283.3 & 49.0 \\
\hline $\mathbf{F}_{4}$ & : & $100 \%$ RDN + Rhizobium & 93.0 & 7.5 & 32.1 & 45.9 & 132.4 & 229.7 & 304.6 & 60.0 \\
\hline $\mathbf{F}_{5}$ & : & $75 \%$ RDN + Rhizobium & 92.5 & 9.0 & 31.2 & 45.2 & 129.3 & 225.3 & 300.2 & 56.6 \\
\hline $\mathbf{F}_{6}$ & $:$ & $50 \%$ RDN + Rhizobium & 91.0 & 8.5 & 30.2 & 43.6 & 112.9 & 197.4 & 287.4 & 53.6 \\
\hline $\mathrm{F}_{7}$ & - & Rhizobium & 89.0 & 8.8 & 26.0 & 37.7 & 95.75 & 155.5 & 190.7 & 29.7 \\
\hline \multicolumn{3}{|c|}{ SEm ( \pm$)$} & 0.71 & - & 0.16 & 0.23 & 4.80 & 2.54 & 2.32 & 4.90 \\
\hline \multicolumn{3}{|c|}{$\mathrm{CD}(\mathrm{P}=0.05)$} & 1.70 & - & 0.38 & 0.55 & 11.53 & 6.10 & 5.57 & 11.77 \\
\hline
\end{tabular}


Table.2 Effect of polythene mulching and rhizobium inoculation on Crop growth rate, yield attributes, pod yield and B:C ratio on rabi groundnut (Pooled over two years)

\begin{tabular}{|c|c|c|c|c|c|c|c|c|c|}
\hline \multirow{2}{*}{\multicolumn{4}{|c|}{ Treatment }} & \multicolumn{2}{|c|}{$\begin{array}{l}\text { Crop Growth Rate }\left(\mathrm{g}^{-1} \mathrm{~m}^{-2}\right. \\
\left.\text { day }^{-1}\right)\end{array}$} & \multicolumn{2}{|l|}{ Yield attributes } & \multirow{2}{*}{$\begin{array}{l}\text { Kernel } \\
\text { yield } \\
\left(\mathrm{kg} \mathrm{ha}^{-1}\right)\end{array}$} & \multirow[t]{2}{*}{ B:C Ratio } \\
\hline & & & & 45-60 DAE & 61-74 DAE & $\begin{array}{l}\text { No. of pegs plant } \\
\text { (at harvest) }\end{array}$ & $100 \mathrm{KW}(\mathrm{g})$ & & \\
\hline \multicolumn{10}{|c|}{ Mulching (M) } \\
\hline$\overline{\mathbf{M}_{0}}$ & : & \multicolumn{2}{|l|}{ Without mulching } & 5.67 & 4.16 & 26.7 & 44.2 & 1869 & 1.98 \\
\hline$\overline{M_{1}}$ & : & \multicolumn{2}{|l|}{ With mulching } & 5.87 & 4.93 & 28.8 & 45.2 & 2376 & 2.33 \\
\hline \multicolumn{4}{|c|}{$\operatorname{SEm}( \pm)$} & 0.54 & 0.13 & 0.16 & 0.16 & 15.45 & - \\
\hline \multicolumn{4}{|c|}{$\mathrm{CD}(\mathrm{P}=0.05)$} & NS & NS & 0.44 & NS & 42.38 & - \\
\hline \multicolumn{10}{|c|}{ Nutrient management (F) } \\
\hline$F_{1}$ & : & \multicolumn{2}{|l|}{$100 \% \mathrm{RDN}$} & 6.30 & 4.43 & 28.6 & 45.4 & 2424 & 2.37 \\
\hline $\mathbf{F}_{2}$ & : & \multicolumn{2}{|l|}{$75 \% \mathrm{RDN}$} & 6.16 & 4.56 & 29.2 & 44.6 & 2270 & 2.28 \\
\hline $\mathbf{F}_{3}$ & : & \multicolumn{2}{|l|}{$50 \% \mathrm{RDN}$} & 6.04 & 4.61 & 26.1 & 43.8 & 2069 & 2.21 \\
\hline $\mathbf{F}_{4}$ & : & $\begin{array}{l}100 \% \text { RDN } \\
\text { Rhizobium }\end{array}$ & & 6.36 & 4.96 & 29.9 & 45.6 & 2479 & 2.45 \\
\hline$\overline{F_{5}}$ & : & $\begin{array}{lc}75 \quad \% & \mathrm{RDN} \\
\text { Rhizobium } & \end{array}$ & & 6.27 & 4.96 & 30.0 & 45.5 & 2410 & 2.37 \\
\hline $\mathrm{F}_{6}$ & : & $\begin{array}{l}50 \quad \% \quad \text { RDN } \\
\text { Rhizobium }\end{array}$ & & 5.44 & 5.97 & 27.8 & 44.3 & 2243 & 2.28 \\
\hline $\mathrm{F}_{7}$ & : & Rhizobium & & 3.85 & 2.32 & 22.8 & 43.7 & 963 & 1.15 \\
\hline \multicolumn{4}{|c|}{$\operatorname{SEm}( \pm)$} & 0.36 & 0.21 & 0.39 & 0.32 & 32.42 & - \\
\hline \multicolumn{4}{|c|}{$\mathrm{CD}(\mathrm{P}=0.05)$} & NS & 0.50 & 0.93 & NS & 77.93 & - \\
\hline
\end{tabular}


Similar finding was also reported by Muhammad et al., (2011) who stated that the rhizobium inoculation significantly enhanced the growth and yield parameters of groundnut cultivars. Dry matter production increased significantly under polythene mulching over without mulch during all the growth stages of the crop. Dry matter production increased gradually with advancement of the crop age and was found maximum at 75 DAE. Mulching had the significant influences to increase the dry matter production as it facilitate the micro climate for the crop which was favourable for partitioning of maximum dry matter towards maturity. Dry matter production decreased with reducing the doses of inorganic nitrogen but it was increased further when isolated efficient rhizobium strain was supplemented with inorganic nitrogen $\left(\mathrm{F}_{4}-\mathrm{F}_{6}\right)$. This might be due to efficient strain of rhizobium had the significant role to fix more nitrogen to the soil and at later stage well established root system helps to uptake more nutrients to the plant as a result of higher dry matter accumulation. Nodule numbers did not vary significantly due to polythene mulching over without mulch but nodule numbers increased significantly with increasing the inorganic nitrogen to groundnut and was found higher when rhizobium was supplemented with $100 \%$ of RDN. Polythene mulching had no significant influence to increase the growth rate over polythene mulching during all the growth stages but nutrient application had the positive influence to accelerate the crop growth towards maturity rather initial growth stage.

\section{Effect on yield attributes and yields of kernel}

Polythene mulching had the profound effect to increase the number of pegs plant ${ }^{-1}$ and significantly higher pegs were found under polythene mulch as compared to without mulch. This was due to mulches provide the favourable microclimate inside the mulch for good growth, branching and early induction of flowering. This finding is an agreement with Kumar and Shivani (2001). Hundred kernel weight did not vary significantly due to polythene mulching over non-mulch. Hundred kernel weights increased with increasing the fertilizer doses and maximum was found in the treatment received $100 \% \mathrm{RDN}+$ isolated Rhizobium.

Hundred kernel weights are mostly governed by genetically. However, isolated Rhizobum without inorganic nitrogen had no significant influence on hundred kernel weights over indigenous microbial strain present in the soil. Significantly higher kernel yield was found under polythene mulching as compared to without mulching. Increasing levels of soil application of inorganic nitrogen up to $100 \%$ increased kernel yield significantly but it was further increased with supplementation of rhizobium. From the table 2 it was found that soil application of inorganic nitrogen could be reduced $25 \%$ with supplementation of rhizobium to achieve optimum kernel yield under the treatment F5 (2410 kg ha $\left.{ }^{-1}\right)$. Higher BCR was found under polythene mulch treatment and $100 \%$ RDN along with rhizobium.

\section{References}

Deshwal, V. K., R. C. Dubey and Maheshwari, D. K. 2003. Isolation of plant growth-promoting strains of Bradyrhizobium (Arachis) sp. With biocontrol potential against Macrophomina phaseolina causing charcoal rot of peanut. Current Science. 84(3): 443-448.

Kamble, D.R., D. N. Gokhale, G. D. Gadade and Jadhav, P. B. 2018. Yield and Economics of Summer Groundnut as Influenced by Different Irrigation Level and Mulches. International Journal of 
Current Microbiology and Applied Sciences. 6: 135-139.

Muhammad, S., R. Abdur, W. Fazal, S. N. M.

Shah, J. Ibadullah, M. A. Khan, S. A. Hussain, M. A. Khan and Zafar, I. 2011. Influence of rhizobium inoculation on growth and yield of groundnut cultivars.
Sarhad Journal of Agriculture. 27(4): 573-576.

Kumar, S. and Shivani 2001. Production potential of rabi groundnut as influenced by polythene mulch in Northeastern India. International Arachis Newsletter. 21: 53-54.

\section{How to cite this article:}

Mousumi Mondal, Sunil Kr. Gunri, Amrita Sengupta and Rajib Kundu. 2018. Productivity Enhancement of Rabi Groundnut (Arachis hypogaea L.) under Polythene Mulching and Rhizobium Inoculation under New Alluvial Zone of West Bengal, India. Int.J.Curr.Microbiol.App.Sci. 7(09): 2308-2313. doi: https://doi.org/10.20546/ijcmas.2018.709.286 